\title{
Translational Cell Carcinoma of the Nose in a Developing Community
}

\author{
Wilson IB Onuigbo* and Basil C Ezeanolue \\ Department of Pathology, University of Nigeria Teaching Hospital, Nigeria
}

Submission: October 26, 2018; Published: November 15, 2018

*Corresponding author: Wilson IBOnuigbo,Department of Pathology, University of Nigeria Teaching Hospital, Enugu 400001, Nigeria

\begin{abstract}
Transitional cell carcinoma of the nasal cavity is rare. Single case reports have appeared in the recent literature. Accordingly, we report a case from a developing community in Nigeria. It is deemed to be worthy of documentation.
\end{abstract}

Keywords: Nose; Transitional cell carcinoma; Different countries; Developing community; Nigeria

\section{Introduction}

The transitional cell carcinoma of the nose is a rarity. Single cases of it have been reported recently from India [1-3] as well as Australia [4]. Therefore, we report a case from Nigeria with special reference to the Ibo ethnic group [5]. It is deemed to be worthy of documentation, especially as it followed the recommendation of a Birmingham (UK) group concerning epidemiological analysis being the result of the establishment of a histopathology data pool [6].

\section{Case Report}

ON, a 70-year-old man of the Ibo ethnic group, attended the Balsam Clinic, Enugu, Nigeria, where Dr Basil Ezeanolue, the junior co-author, attended to him. He complained of left nasal mass associated with bleeding for 3 months. There was a fleshy mass obstructing the left nasal cavity, arising from the ethmoid air cell system. Inverted papilloma was suspected, and biopsy undertaken. Numerous, irregularly surfaced soft, pale masses measuring up to $3.5 \mathrm{~cm}$ across were obtained. On microscopy by the corresponding author, there are benign looking papillary structures as well as mitotically active tumor cells diagnostic of transitional cell carcinoma.

\section{Discussion}

Indian associate mentioned that transitional cell carcinoma is "also known as non-keratinizing carcinoma of sinonasal tract" [2]. They went further to add that "According to the World Health Organization (WHO) classification, it has many synonyms, including, Schneiderian carcinoma, transitional cell carcinoma, cylindrical cell carcinoma, Ringertz carcinoma, and respiratory epithelial carcinoma." Another group included only three of these, namely, "Respiratory epithelial carcinoma, Ringertz carcinoma,
Cylindrical carcinoma" [1].The age range is said to be "most commonly seen in 5 th to 7 th decade" [3]. Our 70-year-old patient is in this range.

\section{Conclusion}

Good news followed a review of the relevant literature which ended nicely thus: "A dramatic and complete tumor response to chemotherapy with cis-platinum, methotrexate, and bleomycin is described in a patient with advanced proptosis due to extensive local recurrence of transitional cell carcinoma" [7]. Of course, this is a fan cry in a developing community such as ours. Indeed, as regards treatment, our patient was lost to follow up.

\section{References}

1. Jhawar K, Jain AK, Nigam R, Manish KS, Freni JK (2014) Transitional cell carcinoma of nasal cavity: A rare case report. J Evolution Med Dent Sci 3(30): 8399-8402.

2. Mondal M, Dey A, Bandyopadhyay, Banerjee D (2015) Transitional cell carcinoma of the sinonasal tract: A rare entity. Clin Cancer Investig J 4(1): 50-53.

3. Vijaya KJ, Kaur P, Khurana A, Chauhan A, Singh G, et al. (2015) Transitional cell papilloma of nasal cavity with malignant transformation. Am J Med Case Rep 3(8): 231-234.

4. Lam W (1981) Transitional-cell carcinoma of the maxillary sinus. Aust Dent J 26(3): 172-174.

5. Basden GT (2015) The Effective Power of Music in Africa. Scientific research 5(3).

6. Macartney JC, Rollaston TP, Codling BW (1980) Use of a histopathology data pool for epidemiological analysis. J Clin Pathol 33(4): 351-353.

7. Sooriyaarachchi GS, Skuta GL, Busse JM (1984) Transitional cell carcinoma of the nasal passages: Dramatic response to chemotherapy. Med Pediar Oncol 12(1): 50-53. 


\section{Your next submission with Juniper Publishers} will reach you the below assets

- Quality Editorial service

- Swift Peer Review

- Reprints availability

- E-prints Service

- Manuscript Podcast for convenient understanding

- Global attainment for your research

- Manuscript accessibility in different formats

( Pdf, E-pub, Full Text, Audio)

- Unceasing customer service

Track the below URL for one-step submission https://juniperpublishers.com/online-submission.php 